\title{
Comparison of Exterior Coatings Applied to Oak Wood as a Function of Natural and Artificial Weathering Exposure
}

\author{
Eliška Oberhofnerová ${ }^{1}$, Kristýna Šimůnková ${ }^{1}$, Ondřej Dvořák ${ }^{1}$, Irena Štěrbová ${ }^{1}$, \\ Salim Hiziroglu ${ }^{2}$, Přemysl Šedivka ${ }^{1}$ and Miloš Pánek ${ }^{1, *}$ \\ 1 Department of Wood Processing and Biomaterials, Faculty of Forestry and Wood Sciences, Czech University \\ of Life Sciences in Prague, Kamýcká 129, 16500 Prague, Czech Republic; \\ Eliska.Oberhofnerova@seznam.cz (E.O.); simunkovak@fld.czu.cz (K.Š.); dvorak18@fld.czu.cz (O.D.); \\ sterbovai@fld.czu.cz (I.Š.); sedivka@fld.czu.cz (P.Š.) \\ 2 Department of Natural Resource Ecology and Management, Oklahoma State University, 303-G Agricultural \\ Hall, Stillwater, OK 74078, USA; salim.hiziroglu@okstate.edu \\ * Correspondence: panekmilos@fld.czu.cz; Tel.: +420-224-383-867
}

Received: 13 November 2019; Accepted: 14 December 2019; Published: 16 December 2019

\begin{abstract}
Artificial weathering can significantly reduce the testing time needed for proving coating durability, nevertheless its reliability is still not thoroughly proven. In this study, eight different transparent and pigmented coating systems, namely oil, acrylate, alkyd and urethane alkyd were evaluated through natural and artificial weathering tests on oak samples by measuring colour, gloss and surface wettability and by macroscopic and microscopic evaluation. The oil coatings performed well in wood colour stability evaluations, while the best gloss and wettability change results were noted for acrylate coatings. Pigmented coatings were characterized by significantly lower colour changes than transparent ones. The gloss and wettability changes were more sensitive to coating disruption than to total colour changes of coated wood associated with chemical changes in wood. The findings in this work showed that values of gloss changes and surface wettability for all types of coatings exposed to artificial and natural weathering resulted in significant differences from each other. The data obtained by artificial weathering method provide basic results of coatings durability and, ideally, natural weathering should be performed at the same time to support the results from laboratory tests by exposing wood under real conditions.
\end{abstract}

Keywords: artificial weathering; coatings; durability; natural weathering; oak wood

\section{Introduction}

Oak (Quercus petraea L.) wood is often used for the exterior applications, mostly in construction of bridges, pergolas, balconies or garden furniture, where higher natural durability [1] is required. Oak contains a relatively high amount of phenol extractives, mainly vescalagin, castalagin, gallic and ellagic acids [2], creating problems in the field of surface treatment durability [3,4]. Tannins in oak wood also retard coating hardening [5]. The complex open vessel morphological structure of oak wood complicates the overall application of coatings. A photodegradation process of oak wood accompanied with significant discolouration and leaching of extractives from the surface takes place during the initial phases of outdoor exposure [6], more intensely in the heartwood zone [7], which leads to the need to protect oak wood by coatings to maintain its natural appearance.

Exterior wood coatings are used to improve the properties of substrate wood [8], reduce the effects of degradation factors [9-11] and prolong the service life of the material. The exterior coating generally protects against moisture uptake and related dimensional changes, protects against photochemical 
degradation, and prevents microbiological degradation $[12,13]$. The problems with transparent coatings have been well discussed by Evans et al. [13]. Their advantage is the ability to protect wood and preserve the natural look and colour [13], but they have the disadvantage of not protecting the substrate wood against UV and visible light radiation as well as pigmented coatings [14]. The different performance of coatings is also caused by their polymer base [15], the type of solvent [16] or even by the underlying wood species $[17,18]$. Coatings protect underlying wood, but they are exposed to weathering process causing their degradation $[17,19,20]$. The durability of coatings against atmospheric degradation is assessed via natural weathering (NW) or artificial weathering (AW) tests $[8,21-25]$ with parameters given in international standards. The older and more common method is natural weathering [26], which provides reliable results of coating durability due to the synergistic action of outdoor factors. Accelerated artificial weathering [27] is carried out in laboratory conditions, to simulate the exterior environment $[22,28]$. Artificial weathering can significantly reduce the required testing time, however its reliability is still often questioned. Correlations between weathering methods were done in several studies [23,29-31] however the results were ambiguous. Valverde and Moya [32] developed a model to predict total colour difference between natural weathering and accelerated weathering for different kinds of finishes of three tropical species. Cogulet et al. [11] focused on how the impacts of different weathering methods challenges the reliability of AW and states that it is necessary to test coating systems in an end-use environment for accurate assessment of their likely performance.

In these works, where wood weathering was studied, more qualitative parameters of wood coatings during both exposures were evaluated-change of colour parameters [3,11,30], coating thickness [23,30], coating adhesion $[30,33]$ or gloss $[3,34]$. Especially the change of colour during weathering serves as a basic indicator of the rate of degradation [18,22,30]. In a study of Moya et al. [30], colour change was higher in all species after NW than after AW due to the constant variation of solar radiation, moisture, water, air contamination and biotic agents, which accelerates colour degradation processes $[8,35]$. These findings are consistent with previous studies indicating the difficulty of reproducing the synergistic action of NW factors during AW $[11,17,23,24,36]$.

Currently there is very limited information on characteristics of transparent and pigmented coatings on oak wood when they are exposed to both natural and artificial weathering. Therefore, the objective of this study was to compare the performance of eight different transparent and pigmented coating systems applied on oak samples using natural and artificial weathering tests. The efficiency of specific coating systems was determined by measurements of colour, gloss and surface wettability changes and by regular visual macroscopic and microscopic evaluation of the samples.

\section{Materials and Methods}

\subsection{Sample Preparation, Coatings and Weathering Process}

Samples of oak (Quercus petraea L.) wood harvested in the Czech Republic having an average oven dry density of $\rho_{0}=705 \mathrm{~kg} / \mathrm{m}^{3}$ [37] were used for the experiment. The samples were conditioned to $12 \pm 2 \%$ moisture content. Test samples were prepared from the heartwood zone and they were visually sorted in order to minimalize the colour variability of the tested wood materials. The dimensions of the samples were $375 \mathrm{~mm} \times 78 \mathrm{~mm} \times 20 \mathrm{~mm}$ for natural weathering and $45 \mathrm{~mm} \times 45 \mathrm{~mm} \times 8 \mathrm{~mm}$ for the artificial weathering tests. Tangential surfaces were exposed to weathering in both cases. Two samples for NW and four samples for AW for each type of treatment were used.

Eight different transparent or pigmented coatings were applied to the samples based on the producer's recommendation. Their specification and application details are given in Table 1. One group of samples was left untreated as control samples to compare coatings performance on treated samples. The cross ends of samples were sealed with silicon to minimize additional water uptake. 
Table 1. Specifications of the tested coatings according to the producers.

\begin{tabular}{|c|c|c|c|c|}
\hline $\begin{array}{l}\text { Coating } \\
\text { Symbol }\end{array}$ & Coating Specification & $\begin{array}{l}\text { Type of } \\
\text { Coating }\end{array}$ & $\begin{array}{l}\text { Transparent (T) or } \\
\text { Pigmented }(\mathrm{P})\end{array}$ & $\begin{array}{l}\text { Number of Layers (Dry } \\
\text { Film Thickness) }\end{array}$ \\
\hline CS & $\begin{array}{l}\text { Control reference (REF) native } \\
\text { samples without any coating system }\end{array}$ & - & - & - \\
\hline $\mathrm{AC} 1$ & $\begin{array}{l}\text { Acrylate thick-layer water-based stain } \\
\quad \text { with fungicides } \\
\text { (5-chloro-2-methylisothiazol-3(2H)-one) }\end{array}$ & Acrylate & $\mathrm{T}$ & $\begin{array}{c}2 \\
(40 \mu \mathrm{m})\end{array}$ \\
\hline $\mathrm{AC} 2$ & $\begin{array}{c}\text { Acrylate thin-layer water-based } \\
\text { coating with a UV light absorber } \\
\text { (1,2-benzoisothiazol-3(2H)-one), IPBC } \\
\text { as fungicide }\end{array}$ & Acrylate & $\mathrm{T}$ & $\begin{array}{c}3 \\
(20 \mu \mathrm{m})\end{array}$ \\
\hline AL1 & $\begin{array}{l}\text { Thixotropic alkyd coating with } \\
\text { microparticles as a UV-stabilizer }\end{array}$ & Alkyd & $\mathrm{T}$ & $\begin{array}{c}3 \\
(40 \mu \mathrm{m})\end{array}$ \\
\hline AL2 & $\begin{array}{l}\text { Thick-layer mixture of alkyds and oils } \\
\text { with IPBC and pigments }\end{array}$ & Alkyd/Oil & $\mathrm{P}$ & $\begin{array}{c}2 \\
(40 \mu \mathrm{m})\end{array}$ \\
\hline O1 & $\begin{array}{l}\text { Thin-layer oil-based with micronized } \\
\text { pigments }\left(\mathrm{TiO}_{2}\right) \text { and fungicides } \\
\text { (propiconazole }<1 \% \text { ) }\end{array}$ & Oil & $\mathrm{P}$ & $\begin{array}{c}2 \\
(10 \mu \mathrm{m})\end{array}$ \\
\hline $\mathrm{O} 2$ & $\begin{array}{l}\text { Thin-layer oil-based with dark } \\
\text { micronized pigments }\left(\mathrm{Fe}_{2} \mathrm{O}_{3}\right) \text { and } \\
\text { fungicides (propiconazole }<1 \% \text { ) }\end{array}$ & Oil & $\mathrm{P}$ & $\begin{array}{c}2 \\
(5 \mu \mathrm{m})\end{array}$ \\
\hline O3 & $\begin{array}{l}\text { Oil-based coating with fungicides } \\
\text { (propiconazole } 0.5 \% \text { ) }\end{array}$ & Oil & $\mathrm{T}$ & $\begin{array}{c}3 \\
(10 \mu \mathrm{m})\end{array}$ \\
\hline S1 & $\begin{array}{l}\text { Thin-layer solvent-based } \\
\text { stain—urethane alkyds with additives } \\
\text { in white spirit with IPBC }\end{array}$ & Urethane alkyd & $\mathrm{P}$ & $\begin{array}{c}2 \\
(25 \mu \mathrm{m})\end{array}$ \\
\hline
\end{tabular}

$$
\text { Note: IPBC = 3-iodo-2-propynyl butylcarbamate. }
$$

The natural weathering (NW) test was performed at Suchdol, Prague $\left(50^{\circ} 07^{\prime} 49.68^{\prime \prime} \mathrm{N}\right.$, $14^{\circ} 22^{\prime} 13.87^{\prime \prime}$ E) for 12 months. The climatic conditions during exposure are given in Table 2. The samples were exposed at a $45^{\circ}$ inclination, facing south, and placed approximately $1 \mathrm{~m}$ above the ground according to the procedure previously described [26].

Table 2. Climatic conditions during NW. use a period (.) for decimals.

\begin{tabular}{ccccccccccccc}
\hline & \multicolumn{11}{c}{ Period of Outdoor Exposure in $\mathbf{2 0 1 8}$ (months) } \\
\hline Measured data per day & $\mathbf{1}$ & $\mathbf{2}$ & $\mathbf{3}$ & $\mathbf{4}$ & $\mathbf{5}$ & $\mathbf{6}$ & $\mathbf{7}$ & $\mathbf{8}$ & $\mathbf{9}$ & $\mathbf{1 0}$ & $\mathbf{1 1}$ & $\mathbf{1 2}$ \\
Average temperature $\left({ }^{\circ} \mathrm{C}\right)$ & 3.5 & -1.9 & 2.1 & 13.8 & 17.4 & 18.7 & 21.6 & 22.0 & 16.0 & 10.7 & 4.7 & 2.9 \\
Average relative humidity $(\%)$ & 81.2 & 73.4 & 70.3 & 57.8 & 59.7 & 63.4 & 49.2 & 53.4 & 64.0 & 70.3 & 84.5 & 82.2 \\
Total precipitation $(\mathrm{mm})$ & 17.2 & 4.6 & 29.1 & 14.2 & 20.8 & 87.9 & 8.8 & 56.5 & 43.5 & 23.9 & 6.5 & 40.6 \\
Average solar radiation $\left(\mathrm{kJ} / \mathrm{m}^{2}\right)$ & 2432 & 6473 & 8305 & 17,365 & 21,428 & 20,253 & 22,177 & 18,250 & 12,455 & 7915 & 3280 & 1992 \\
\hline
\end{tabular}

Note: based on the data from http://meteostanice.agrobiologie.cz [38].

The artificial weathering (AW) test was performed in UV-chamber QUV (Q-Lab, Cleveland, OH, USA) according to a modified EN 927-6 method [27]. The total time consisted of six cycles (1008 h) of weathering in the UV chamber and $36 \mathrm{~h}$ of temperature cycling. During the each weekly cycle of irradiation and spraying, the samples were transferred to a Discovery My DM340 conditioning chamber (ACS, Massa Martana, Italy) and exposed to three cycles each lasting $2 \mathrm{~h}$ of temperature changes from -25 to $+80{ }^{\circ} \mathrm{C}$ (with $25 \% \mathrm{RH}$ ). The alternation of UV radiation, spray, and low temperature cycles, leading to a better imitation of the exterior conditions in Central and Northern Europe, was previously used by Van den Bulcke et al. and Pánek et al. [22,39].

\subsection{Colour Change $\left(\Delta E^{*}\right)$ Test}

Colour variations of the specimens were evaluated through natural and artificial weathering exposure of oak samples with 8 different coatings. The colour parameters $L^{*} a^{*} b^{*}[40]$ of the test 
specimens were measured after 0, 6 and 12 months of NW and after 0, 1, 3 and 6 weeks of AW using CM-600d Spectrophotometer (Konica Minolta, Osaka, Japan). For the observation of reflection, the specular component was included (SCI mode) at a $10^{\circ}$ angle and $\mathrm{d} / 8$ geometry with an illumination standard of D65 (corresponding to daylight in $6500 \mathrm{~K}$ ). Six measurements of each tested sample were carried out for each weathering time. Colour changes evaluations were done in CIE $\mathrm{L}^{*} \mathrm{a}^{*} \mathrm{~b}^{*}$ colour space where $L^{*}$ is lightness from 0 (black) to 100 (white); $a^{*}$ is chromaticity coordinate + (red) or (green); $b^{*}$ is chromaticity coordinate + (yellow) or - (blue).

The total colour difference $\Delta \mathrm{E}^{*}[40]$ was subsequently calculated from relative changes of colour $\left(\Delta \mathrm{L}^{*}, \Delta \mathrm{a}^{*}\right.$, and $\left.\Delta \mathrm{b}^{*}\right)$ using Equation (1):

$$
\Delta \mathrm{E}^{*}=\sqrt{\left(\Delta \mathrm{L}^{*}\right)^{2}+\left(\Delta \mathrm{a}^{*}\right)^{2}+\left(\Delta \mathrm{b}^{*}\right)^{2}}
$$

\subsection{Gloss Change $\left(\Delta G^{*}\right)$ Test}

The gloss of the different coatings before and during weathering tests was measured using MG268-F2 glossmeter (KSJ, Quanzhou, China) on the basis of [41]. Six measurements at a $60^{\circ}$ angle per sample after 0,6 and 12 months of NW and after $0,1,3$, and 6 weeks of AW were carried out to evaluate gloss changes of the samples.

\subsection{Surface Wettability Change $\left(\Delta W^{*}\right)$ Test}

The sessile drop method with static contact angle measurement was performed using a Krüss DSA $30 \mathrm{E}$ goniometer (Krüss, Hamburg, Germany) with the methodology used in previous studies [42,43]. Twenty measurements were taken for each sample, with distilled water drops with a dosing volume of $5 \mu \mathrm{L}$. The contact angle values were determined after $5 \mathrm{~s}$ of drop deposition on surface of the sample before weathering and after 0,6 and 12 months of NW and after 0, 1, 3 and 6 weeks of AW.

\subsection{Macroscopic and Microscopic Evaluation}

Tested surfaces of the samples were regularly macroscopically evaluated using a Canon 2520 MFP scanner with 300 DPI resolution (Canon, Tokyo, Japan). Creations of cracks, defoliation of coating systems were visually analysed. Microscopic structural changes of coatings and surface of the samples, creation of ruptures, 3D-images of surface profiles were also studied employing confocal laser scanning microscope Lext Ols 4100 (Olympus, Tokyo, Japan) with 108-fold magnification.

\subsection{Statistical Analysis}

Data were analysed using MS Excel (Microsoft, Redmond, WA, USA) and STATISTICA 13.2 (StatSoft, Palo Alto, CA, USA) using mean values, bar graphs and ANOVA for analysing the statistical significance of selected factors with significance level $\alpha=0.05$. Spearman rank correlation between NW after 12 months and AW after 6 weeks on the basis of $\Delta \mathrm{E}^{*}, \Delta \mathrm{L}^{*}, \Delta \mathrm{G}^{*}$ and $\Delta \mathrm{W}^{*}$ values of tested coatings was also analysed. The Spearman rank correlation coefficient was calculated by Equation (2):

$$
R h o_{s}=1-\left[\frac{6 \cdot \sum(\text { Rank Difference })^{2}}{n^{3}-n}\right]
$$

where $n$ is number of items evaluated.

\section{Results and Discussion}

Results on coated samples exposed to artificial and natural weathering showed different behaviours. The type of coating system applied on oak wood samples has a statistically significant effect $(p<0.05)$ on the evaluated properties both during AW and NW (Table 3). 
Table 3. Statistical evaluation of significance of selected factors.

\begin{tabular}{cccccc}
\hline & & $\Delta \mathbf{L}^{*}$ & $\Delta \mathbf{E}^{*}$ & $\Delta \mathbf{G}^{*}$ & $\Delta \mathbf{W}^{*}$ \\
\hline Type of coating & AW & $0.000^{*}$ & $0.001^{*}$ & $0.000 *$ & $0.000^{*}$ \\
system & NW & $0.000 *$ & $0.000 *$ & $0.000 *$ & $0.000 *$ \\
\hline
\end{tabular}

${ }^{*}$ signifies $p<0.05$ (statistically significant at significance level 0.05 ).

\subsection{Colour Change of the Samples}

Total colour difference $\Delta \mathrm{E}^{*}$ calculated from measured colour parameters was the main indicator representing coating durability during weathering $[18,22,30]$. The specific colour parameters $\left(\mathrm{L}^{*}, \mathrm{a}^{*}, \mathrm{~b}^{*}\right)$ describe the colour change more closely. During AW, the observed increase of values a* and decrease of $b^{*}$ values showed a tendency of the wood surface to turn reddish and become less yellow shade. Decreases of both $\mathrm{a}^{*}$ and $\mathrm{b}^{*}$ parameters were observed during $\mathrm{NW}$, which indicates the opposite trend. But in most cases, $\Delta \mathrm{E}^{*}$ was affected mainly by changes in lightness $\left(\Delta \mathrm{L}^{*}\right)$ as in the study of Oberhofnerová et al. [31]. Changes in lightness of different coating during weathering is illustrated in Figure 1. There are obvious differences in lightness parameters based on the weathering type-decrease (negative value) of lightness during AW (except reference samples) indicating a tendency to turn into darker and increase during NW indicating lightening. This trend is caused by the different weathering conditions and ratio of degradation and leaching of photodegraded extractives and lignins observed mainly on the transparent tested coatings. NW differing also in the presence of mould and dust and other pollution in exterior which infiltrate in the degraded surface of wood or coating [10]. These conditions are not simulated in laboratory testing [21,43]. But darkening of the surfaces caused by the action of pollutants and moulds was negligible during this period of NW and mainly leaching of darker oak extractives and changes in pigmented coatings caused increasing of $\mathrm{L}^{*}$ parameter.

Total colour difference $\left(\Delta \mathrm{E}^{*}\right)$ of tested coatings, was closely linked to lightness changes. Control samples manifested the highest colour differences during both types of weathering. Total colour difference values are characterized by a systematic increase during exposure [43,44], with higher changes during initial phases of weathering $[28,43]$. In this study, only coatings AC2 and AL1 followed this trend during AW (Figure 2). The lowest colour difference was noticed for O1 during AW and O2 during NW, which is in accordance with lightness changes in Figure 1. Those were the only coatings able to protect the wood to the extent of $\Delta \mathrm{E}^{*}<3$, which is considered as a low colour difference that cannot be distinguished by a subjective observer [45]. These oil coatings differed from each other only by the type of pigments used (Table 1). The pigmented coatings (O1, O2, AL2, S1) were characterized by significantly lower colour changes than transparent ones.

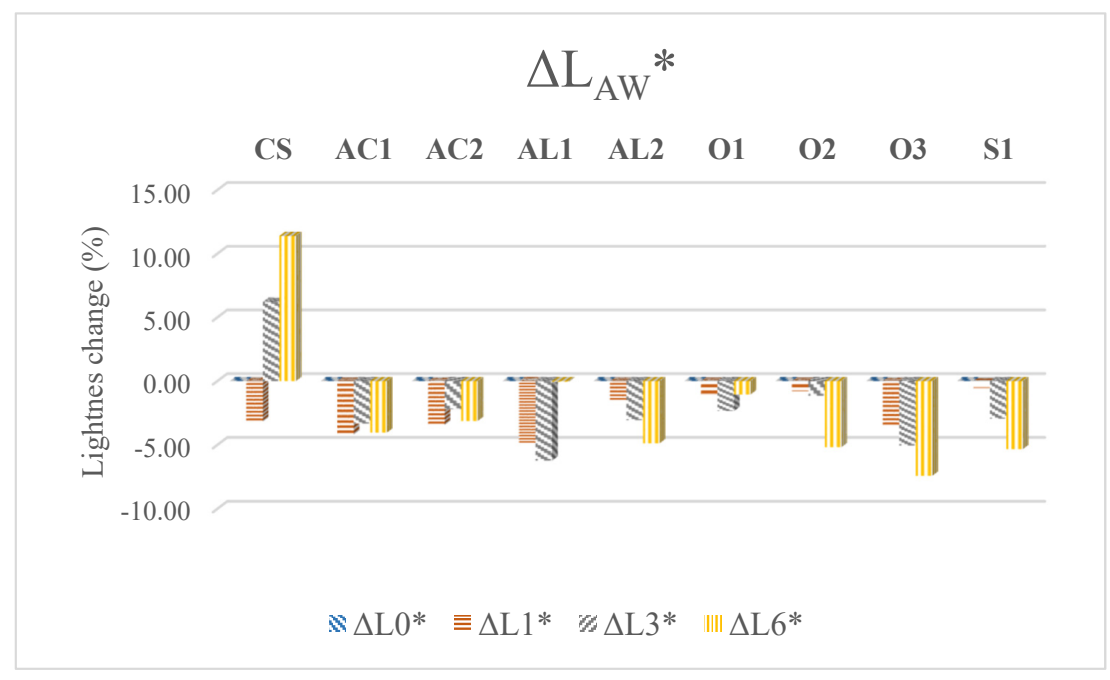

Figure 1. Cont. 


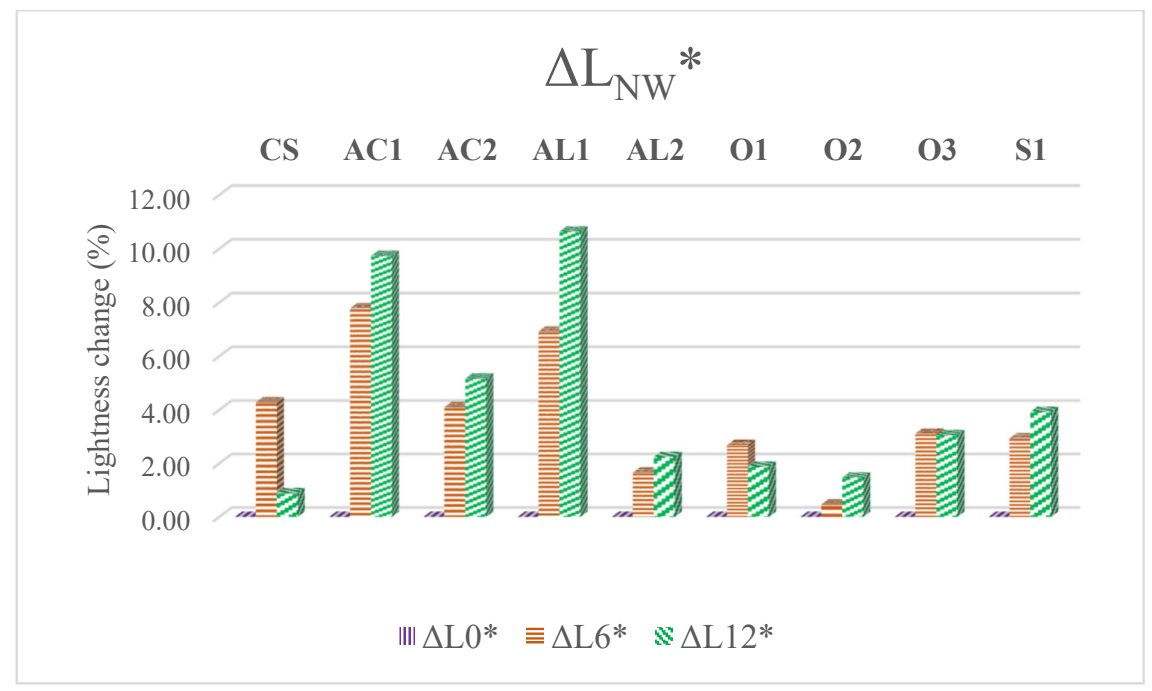

Figure 1. Lightness difference $\left(\Delta \mathrm{L}^{*}\right)$ of tested coating systems during artificial and natural weathering (CS means control sample).

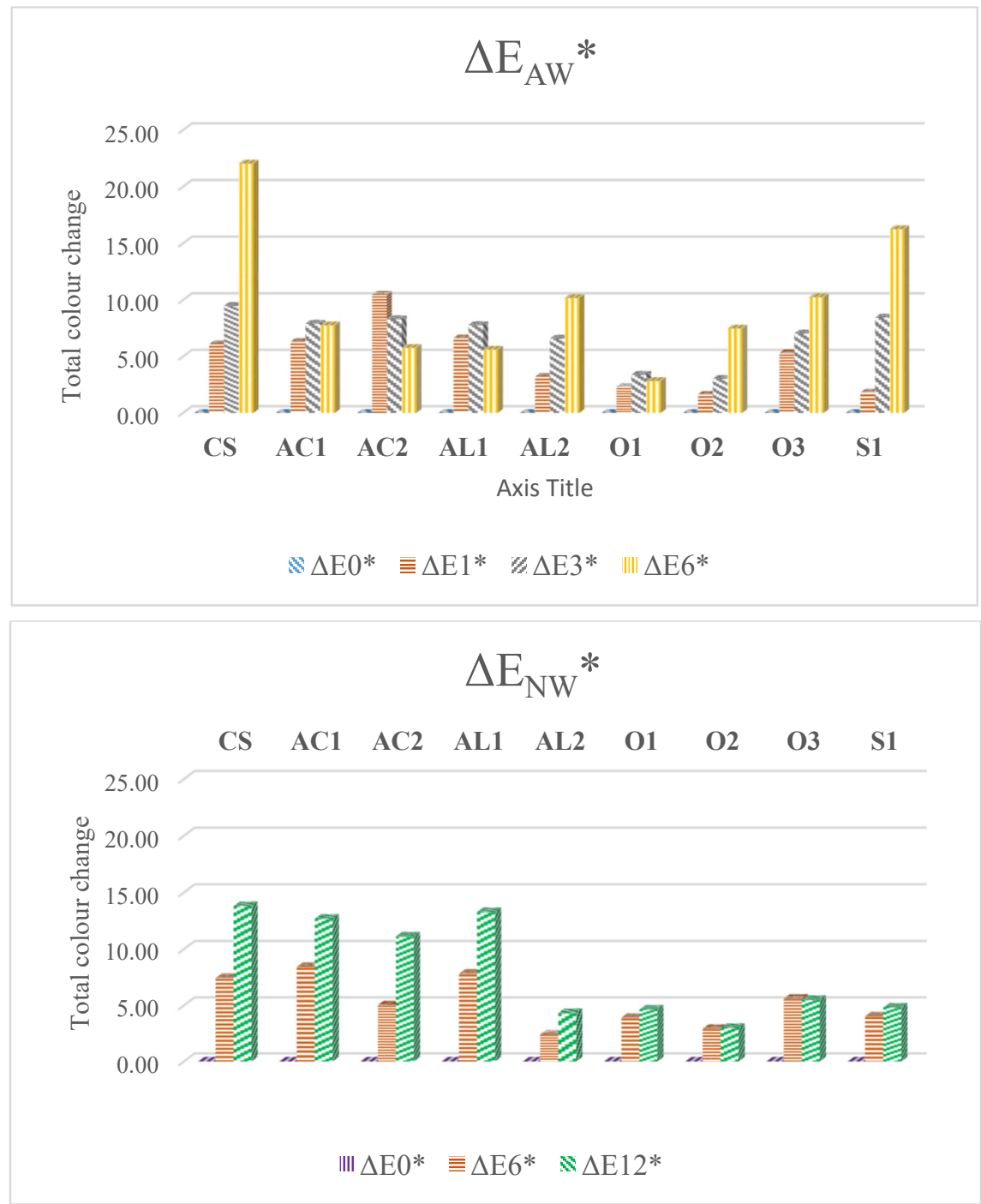

Figure 2. Total colour difference $\left(\Delta \mathrm{E}^{*}\right)$ of tested coating systems during artificial and natural weathering (CS means control sample). 


\subsection{Gloss Change of the Samples}

Except for small fluctuations, all coatings were characterized by decreased gloss values during both weathering methods (Figure 3). The reference samples, on the other hand, manifested increases in this property (with the decrease in the final phase of NW). The same findings regarding protected and unprotected weathered wood were found by Ghosh et al. [46]. The best results were noted for acrylate and AL1 coatings, while the highest changes were recorded for oil coatings.

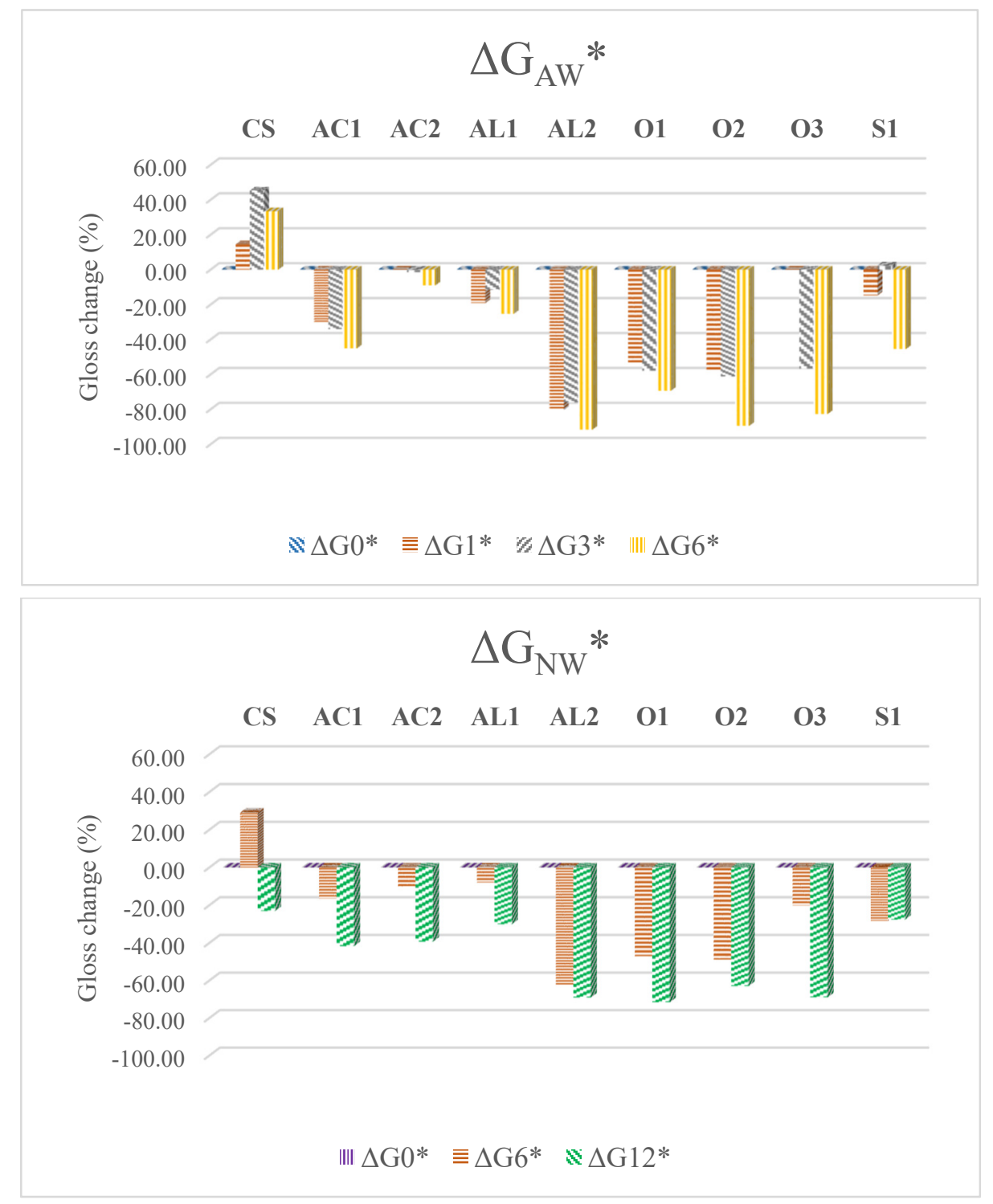

Figure 3. Gloss difference $\left(\Delta \mathrm{G}^{*}\right)$ of tested coating systems during artificial and natural weathering (CS means control sample).

\subsection{Surface Wettability of the Samples}

The contact angle, which indicates the wettability by water on the exposed surfaces of coated wood, is an important indicator of the rate of weathering [22,24]. Surface wetting changes (Figure 4) indicated the overall impairment of the protective function of the coating systems against water $[24,39]$. During AW, the most stable values were noted for acrylate coating systems and O3. The rest of the samples were characterized by decreased surface wettability (the most in the case of reference samples and AL2). During NW, the wettability decreased for all samples, but the smallest changes were also recorded for acrylate and $\mathrm{O} 3$ coating. 


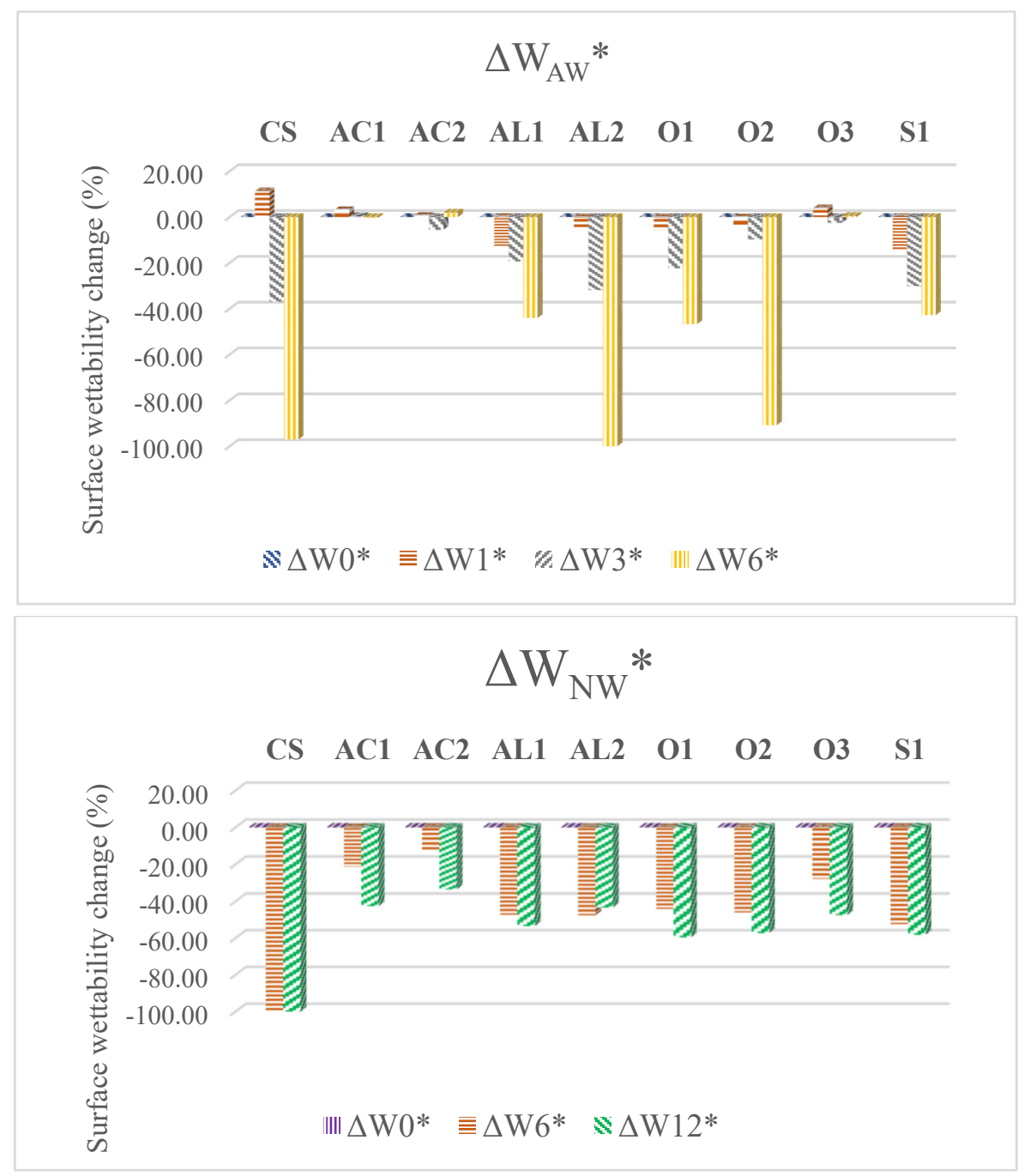

Figure 4. Surface wettability difference $\left(\Delta \mathrm{W}^{*}\right)$ of the tested coating systems during artificial and natural weathering (CS means control sample).

The Spearman rank correlation of properties after 12 months of NW in comparison with 6 weeks of AW measured both the strength and direction of the relationship between the ranks of data (Table 4).

Table 4. Spearman rank correlation between AW and NW.

\begin{tabular}{|c|c|c|c|c|}
\hline & Type of Coating & Number of Valid Tests & Spearman $\mathbf{R}$ & $p$-Value \\
\hline \multirow{3}{*}{$\Delta \mathrm{E}_{6 \mathrm{AW}} * \Delta \mathrm{E}_{12 \mathrm{NW}} *$} & Transparent & 5 & 0.10 & 0.87 \\
\hline & Pigmented & 4 & 0.40 & 0.60 \\
\hline & All coatings & 9 & 0.18 & 0.64 \\
\hline \multirow{3}{*}{$\Delta \mathrm{L}_{6 \mathrm{AW}} * \Delta \mathrm{L}_{12 \mathrm{NW}} *$} & Transparent & 5 & -0.10 & 0.87 \\
\hline & Pigmented & 4 & -0.40 & 0.60 \\
\hline & All coatings & 9 & -0.03 & 0.93 \\
\hline \multirow{3}{*}{$\Delta \mathrm{G}_{6 \mathrm{AW}} * \Delta \mathrm{G}_{12 \mathrm{NW}} *$} & Transparent & 5 & 0.90 & $0.04 *$ \\
\hline & Pigmented & 4 & 0.40 & 0.60 \\
\hline & All coatings & 9 & 0.77 & $0.02 *$ \\
\hline \multirow{3}{*}{$\Delta \mathbf{W}_{6 \mathrm{AW}} * \Delta \mathbf{W}_{12 \mathrm{NW}} *$} & Transparent & 5 & 0.90 & $0.04 *$ \\
\hline & Pigmented & 4 & -0.80 & 0.20 \\
\hline & All coatings & 9 & 0.53 & 0.14 \\
\hline
\end{tabular}

Note: * means statically significant at $95 \%$ level $(p<0.05) ; R=1$ is a perfect positive correlation; $R=-1$ is a perfect negative correlation; $\mathrm{R}=0$ is no correlation. 
Based on the results of Spearman rank correlation, strong statistically significant relationships between results from AW and NW were only found with gloss changes of all coatings and surface wettability changes and gloss changes of transparent coatings $(p<0.05)$. Further evaluation revealed the remaining results from $\mathrm{AW}$ and $\mathrm{NW}$, including total colour difference were statistically insignificant $(p>0.05)$ and very poorly correlated with each other.

\subsection{Macroscopic and Microscopic Evaluation of the Samples}

The coating performance of the samples during NW was also evaluated visually in accordance with other studies $[18,20]$. The visual evaluation confirmed that weathering causes colour changes and surface degradation both in natural and laboratory conditions [23,24]. Visual inspection (Figure 5 for AW and Figure 6 for NW) confirmed the exact previously measured values-darkening of coated samples during AW and lightening of samples during NW (Figure 1) and associated total colour $\left(\Delta \mathrm{E}^{*}\right)$ and gloss changes (Figures 2 and 3).

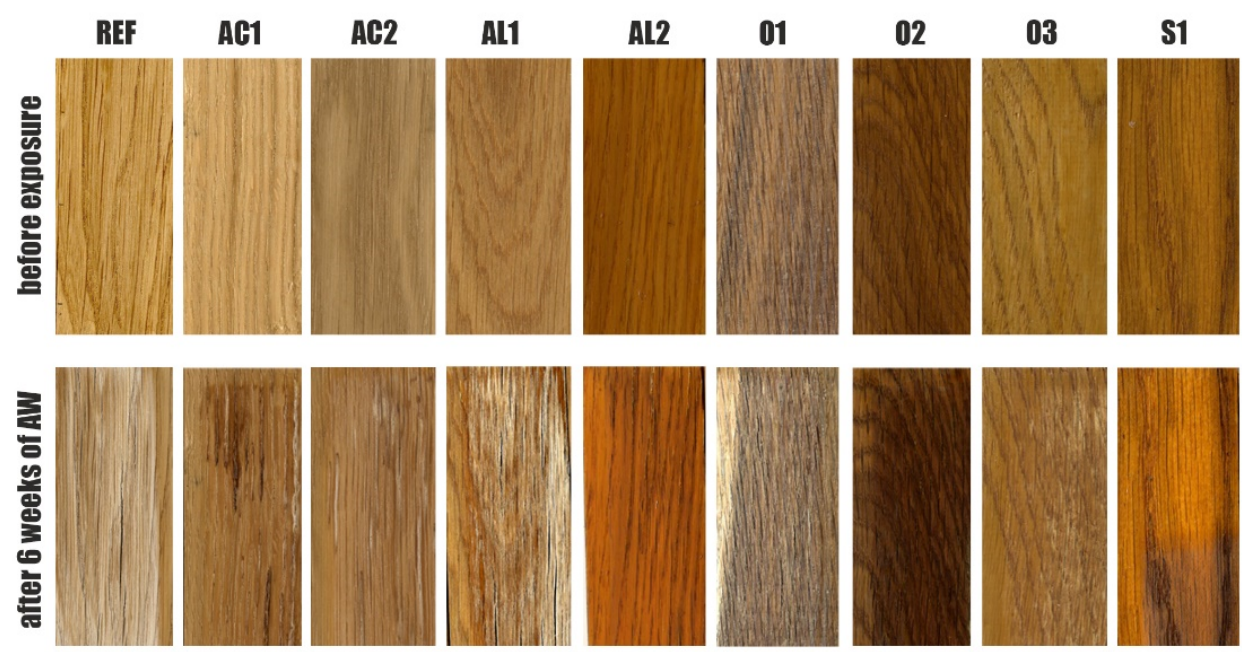

Figure 5. Visual evaluation of tested coatings before and after 6 weeks of AW exposure.

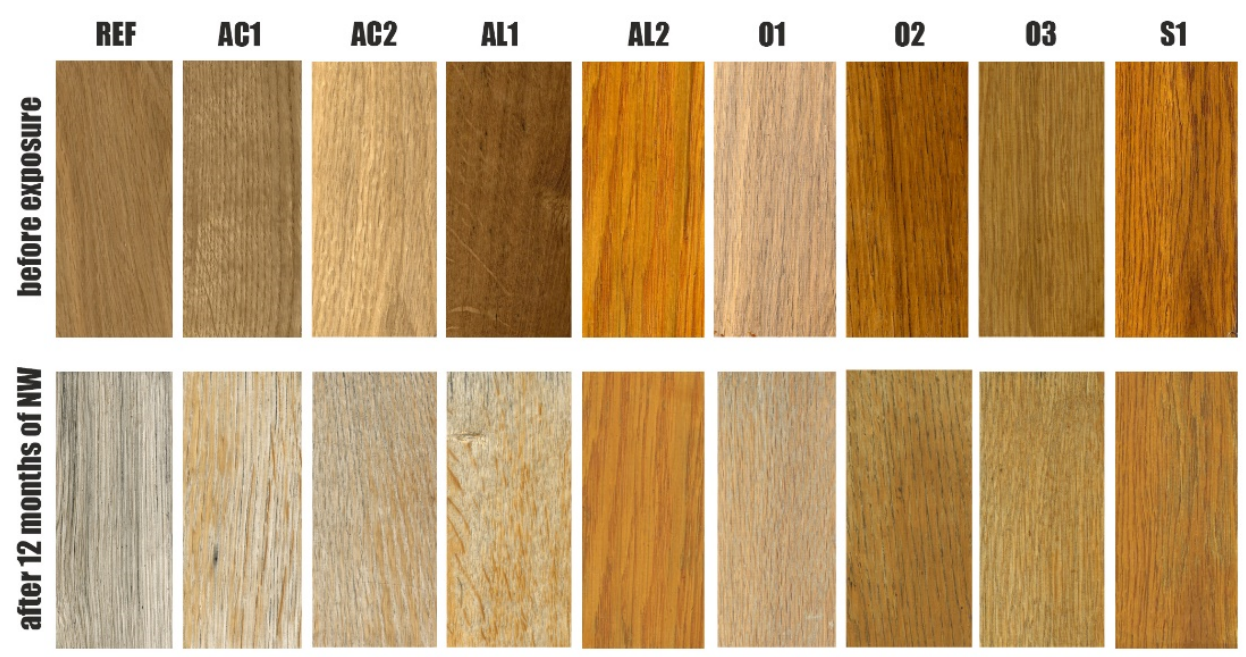

Figure 6. Visual evaluation of tested coatings before and after 12 months of NW exposure.

Confocal laser scanning microscopy was employed to assess degradation of selected coatings. Figure 7 illustrates the degradation of oil coating (O1) and acrylate coating (AC1) after 6 weeks of AW or 12 months of NW. Lower colour changes were noted for oil coatings (Figure 2), but also a more obvious disruption and degradation of the coating surface (Figure 7) which are more connected with the higher gloss and surface wettability changes. In the line with this, the acrylate coatings were 
characterized by lower gloss and surface wettability changes associated with the lower degree of coating degradation.
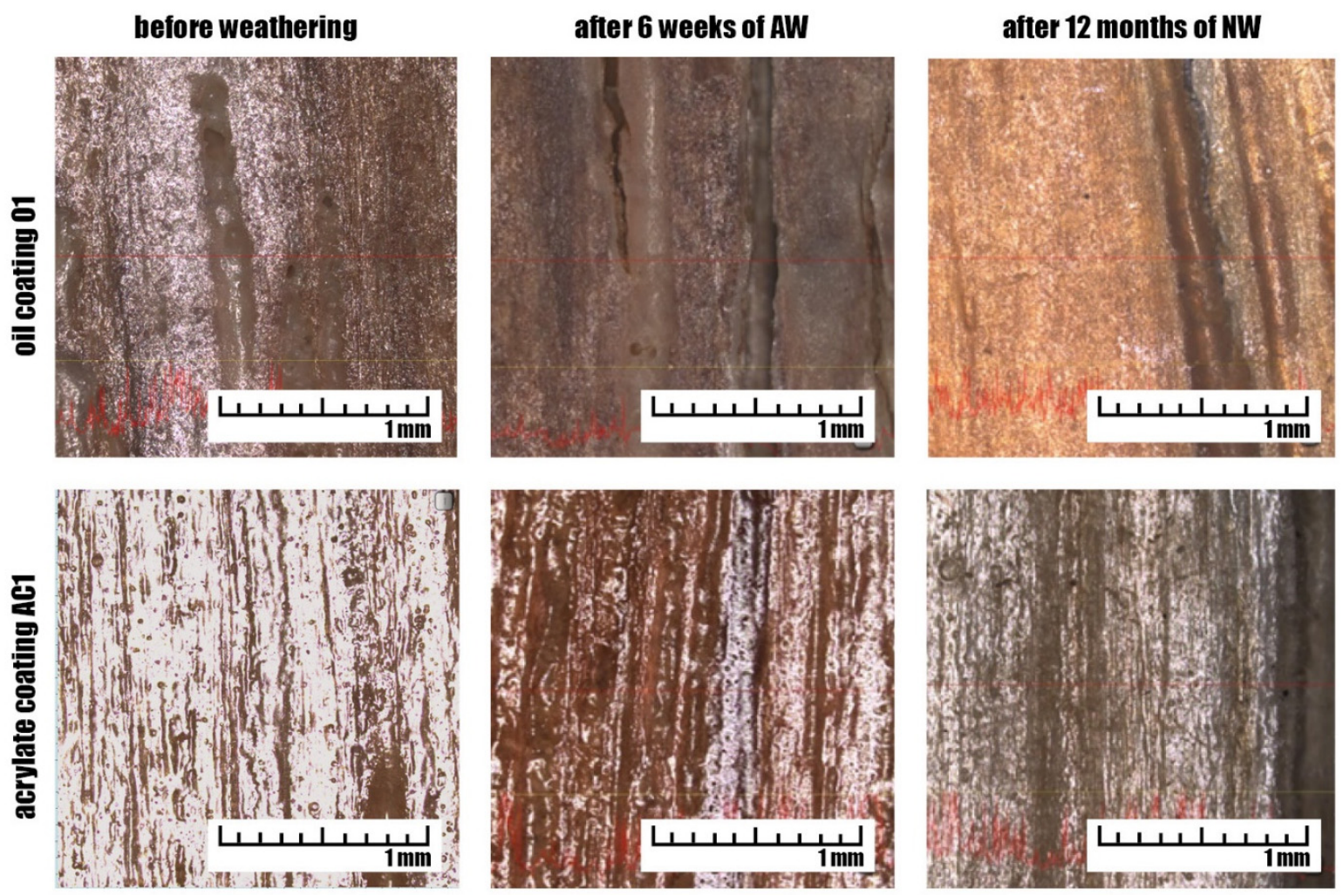

Figure 7. Confocal microscopy of oil (O1) and acrylate (AC1) coating after 6 weeks of AW and 12 months of NW.

3D images of samples roughness profile for selected tested coatings with higher gloss change (AL2 and O3) are shown in Figure 8. It is possible to see increasing of roughness of the surfaces after 6 weeks of accelerated weathering. These images (Figure 8) also confirm that decreasing of gloss is influenced mainly by decomposition of coating film (O3) or its top layer (AL2) (see also Figure 5).

Native oak wood has higher natural durability and lower colour changes in comparison with other hardwood species during weathering [47], but to find durable coatings systems suitable for its specific chemical and morphological structure is desirable. The findings of this study confirmed the effect of polymer base on the overall performance of coatings [12,48]. It is clear that effect of surface protection against weathering was demonstrated by the difference between uncoated reference and coated samples (Figures 1-6). Generally, the oil coatings (O1-O3) performed well in the colour analyses, the acrylate coatings (AC1-AC2) reached the best results in the gloss and wettability evaluation. These properties are more likely connected with coating degradation and disruption than with chemical changes in wood [34,39]. Acrylate and oil coatings reached the best performance on larch wood also in study of Šimůnková et al. [15]. In opposite, in the study of Sivrikaya et al. [48], the better performance against atmospheric conditions on oak wood was recorded for alkyd coatings compared with other tested coatings. 

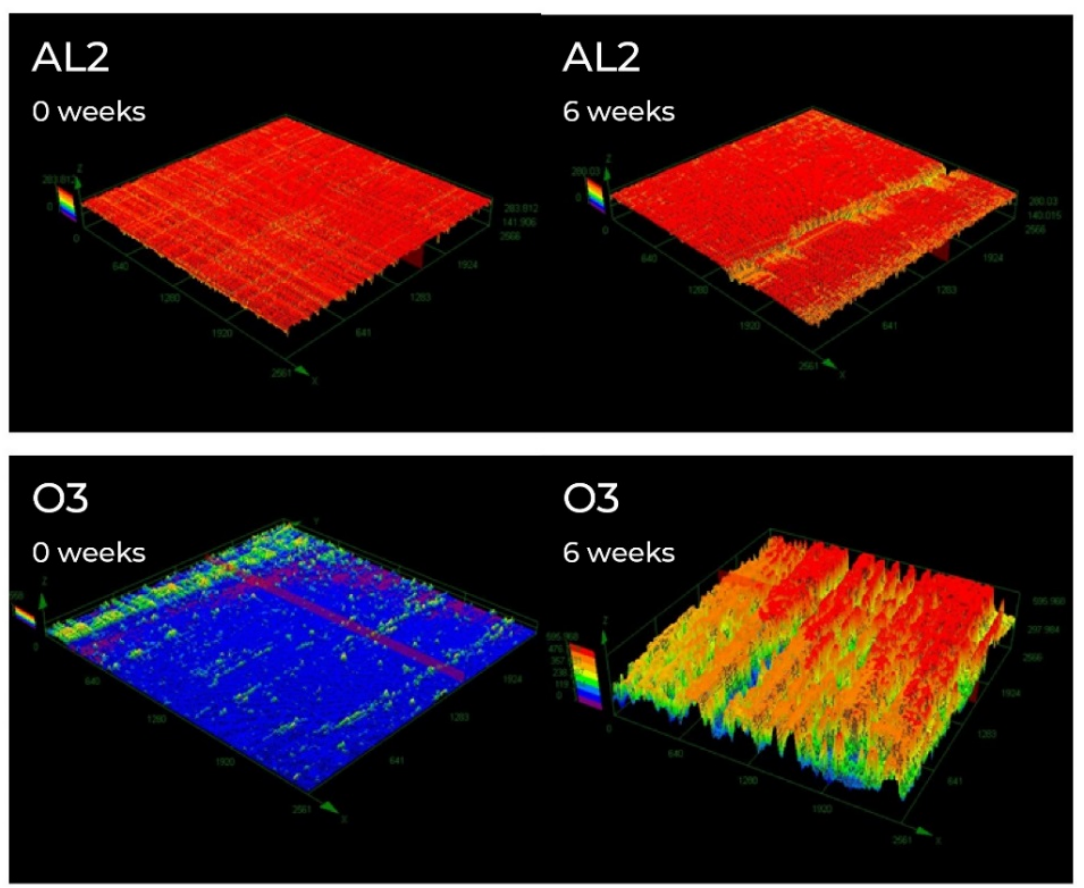

Figure 8. 3D images of surfaces before (left) and after 6 weeks of artificial accelerated weathering (right). Figures were created using Confocal laser scanning microscope with 108-fold magnification. Size of analysed area is $2560 \mu \mathrm{m} \times 2560 \mu \mathrm{m}$.

The total colour changes $\left(\Delta \mathrm{E}^{*}\right)$ were the most connected with the change of lightness parameter $\Delta \mathrm{L}^{*}$ (Figures 1 and 2 ) as in the other studies [43,49]. The lowest colour changes were observed for oil coatings $\mathrm{O} 1$ and $\mathrm{O} 2$ (thin-layer oil-based with micronized pigments $\mathrm{TiO}_{2}$ and $\mathrm{Fe}_{2} \mathrm{O}_{3}$ ). The positive effect of white $\mathrm{TiO}_{2}$ pigments on photodegradation was already discussed in the work of Moya et al. [30]. The thickness of the coating system is a criterion affecting its service life [23] but for tested coatings in this work, the pigment content was the more important factor (Table 1, Figures 5 and 6). The pigmented coatings generally provided more effective protection and reached the lower colour changes during NW than transparent ones as in the study of Sivrikaya et al. [48].

In the gloss and surface wettability evaluation of the samples, the performance of coating differed in comparison with colour analysis. All the tested samples except control samples were noted for loss of gloss during NW and AW. The best results were observed for acrylate AC1-AC2 and AL1 coatings. Although the role of gloss change is still discussed - according to Pánek et al. [39], the gloss change is more sensitive to the coating degradation than to total colour difference (Figure 8). Merlatti et al. [34] stated that loss of gloss should not be systematically correlated to the advance in chemical degradation during weathering. The lowest change of surface wettability was recorded for acrylate coating systems AC1-AC2 and oil coating O3 both after AW and NW. The rest of the samples were characterized by decrease of surface wettability, this was the most significant in the case of control and AL2 samples.

The comparison of both weathering methods only by evaluating colour difference would be insufficient, as stated in other previously done studies $[23,28,30]$. The combination of different testing parameters of coating systems and visual evaluation gives a better idea about the durability of coatings [49,50], despite that the total colour difference still remains the main indicator of coating degradation. Coatings defoliated after AW were in most cases highly degraded after 12 months of NW (Figure 5 versus Figure 6). Based on this, AW can be recommended as the first step for selection of nondurable coatings mainly on woods with specific chemical or morphological structure. The non-linear correlations were performed to compare the strength of the relationship between the total colour differences, gloss and surface after NW and AW of transparent and pigmented coatings as in the study of Pánek and Reinprecht [51]. The results were highly varied, and, in the most cases, without any statistical significance. Comparisons of colour changes mainly showed weak correlation for tested 
oak, as for black locust and spruce wood in the work Pánek and Reinprecht [52]. The strong correlation was found only for the gloss changes of all coatings, in agreement with the work Q-Lab [53], and surface wettability and gloss change of transparent coatings separately. Both methods revealed the certain durability among the tested coating systems and come to the greater agreement than in the case of unprotected wood weathering. These inconsistent results confirm the previously stated difficulty to mathematically correlate data from outdoor and laboratory conditions [22,30]. The significant impact of climatic and local environmental conditions at the testing site is still one of the dominant factors preventing the accurate prediction of real weathering in the exterior via artificial accelerated weathering [36,54]. Even there is an effort to simulate outdoor conditions in UV chamber by setting the parameters of weathering, the more accurate correlation for prediction changes of coated wood via artificial weathering in laboratory has proven to be difficult. Despite the obvious advantages of artificial weathering, the results provided by this method still lack reliability of natural weathering and they should always be carefully interpreted and in the best scenario accompanied by natural weathering tests to verify the performance of coatings in an end-use environment [11].

\section{Conclusions}

Eight different transparent and pigmented coating systems were applied on oak samples and tested using artificial and natural weathering. Total colour difference was mostly related to the lightness parameter change. Evaluation of discolouration with other criteria such as gloss, surface wettability and visual and microscopic evaluation more accurate predicted service life of coatings. Pigmented coatings had significantly lower colour changes than transparent ones, for both artificial and natural weathering. Oil coatings were more colour stable, acrylate coatings achieved the best results of gloss and wettability changes. The gloss and surface wettability changes better copy degradation and disruption of coated wood in comparison with total colour changes. Even there were some visually observed similarities in the test results of AW and NW exposed samples, this was not confirmed statistically. The Spearman rank correlation showed strong statistically significant relationship between results after artificial and natural weathering only for the gloss changes of all coatings and surface wettability and gloss changes of transparent coatings separately.

Author Contributions: Conceptualization and Methodology M.P.; Formal Analysis, E.O.; Investigation, K.Š., O.D., I.Š.; Writing—Original Draft Preparation, E.O.; Writing—Review \& Editing, E.O., M.P., S.H.; Supervision, M.P.; Project Administration, P.Š.

Funding: This work was supported by the grant "Improving of coatings durability on selected kinds of wood in the exterior applications," No. TH02020873, financed by TA ČR.

Conflicts of Interest: The authors declare no conflict of interest.

\section{References}

1. EN 350. Durability of Wood and Wood-Based Products-Testing and Classification of the Durability to Biological Agents of Wood and Wood-Based Materials; European Committee for Standardization: Brussels, Belgium, 2016.

2. Zahri, S.; Belloncle, C.; Charrier, F.; Pardon, P.; Quideau, S.; Charrier, B. UV light impact on ellagitannins and wood surface colour of European oak (Quercus petraea and Quercus robur). Appl. Surf. Sci. 2007, 253, 4985-4989. [CrossRef]

3. Sivrikaya, H. Impregnability and Durability Characteristics of Sapwood and Heartwood. Ph.D. Thesis, Zonguldak Karaelmas University, Graduate School of Natural and Applied Sciences, Zonguldak, Turkey, 2003.

4. Ayadi, N. Vieillissement Climatique d'un Systéme Bois-Vernis-Absorbeur UV Inorganique. Ph.D. Thesis, Université de Nantes, Nantes, France, 2004.

5. Browne, F.L. Wood Properties that Affect Paint Performance; U.S. Forest Service, Forest Products Laboratory: Madison, WI, USA, 1958.

6. Oberhofnerová, E.; Pánek, M.; García-Cimarras, A. The effect of natural weathering on untreated wood surface. Maderas Ciencia y Tecnología 2017, 19, 173-184. [CrossRef] 
7. George, B.; Suttie, E.; Merlin, A.; Deglise, X. Photodegradation and photostabilisation of wood-The state of the art. Polym. Degrad. Stab. 2005, 88, 268-274. [CrossRef]

8. Auclair, N.; Riedl, B.; Blanchard, V.; Blanchet, P. Improvement of photoprotection of wood coatings by using inorganic nanoparticles as ultraviolet absorbers. For. Prod. J. 2011, 61, 20-27. [CrossRef]

9. Feist, W.C.; Hon, D.N.S. Chemistry of weathering and protection. In The Chemistry of Solid Wood; ACS: Washington, DC, USA, 1984; pp. 401-451.

10. Evans, P.D. Weathering and photoprotection of wood. In Development of Commercial Wood Preservatives; ACS: Washington, DC, USA, 2008; Volume 982, pp. 69-117. [CrossRef]

11. Cogulet, A.; Blanchet, P.; Landry, V. Evaluation of the impacts of four weathering methods on two acrylic paints: Showcasing distinctions and particularities. Coatings 2019, 9, 121. [CrossRef]

12. De Meijer, M. Review on the durability of exterior wood coatings with reduced VOC-content. Prog. Org. Coat. 2001, 43, 217-225. [CrossRef]

13. Evans, P.; Haase, J.; Seman, A.S.B.M.; Kiguchi, M. The search for durable exterior clear coatings for wood. Coatings 2015, 5, 830-864. [CrossRef]

14. Miniutti, V.P. Microscale changes in cell structure at softwood surfaces during weathering. For. Prod. J. 1964, 14, 571-576.

15. Šimůnková, K.; Oberhofnerová, E.; Reinprecht, L.; Pánek, M.; Podlena, M.; Štěrbová, I. Durability of selected transparent and semi-transparent coatings on Siberian and European larch during artificial weathering. Coatings 2019, 9, 39. [CrossRef]

16. Forsthuber, B.; Ecker, M.; Truskaller, M.; Grüll, G. Rapid prediction of surface characteristics of European and Siberian larch wood by FT-NIRS. Eur. J. Wood Wood Prod. 2017, 75, 569-580. [CrossRef]

17. Gobakken, L.R.; Lebow, P.K. Modelling mould growth on coated modified and unmodified wood substrates exposed outdoors. Wood Sci. Technol. 2010, 44, 315-333. [CrossRef]

18. De Windt, I.; Van den Bulcke, J.; Wuijtens, I.; Coppens, H.; Van Acker, J. Outdoor weathering performance parameters of exterior wood coating systems on tropical hardwood substrates. Eur. J. Wood Wood Prod. 2014, 72, 261-272. [CrossRef]

19. Gaylarde, C.C.; Morton, L.H.G.; Loh, K.; Shirakawa, M.A. Biodeterioration of external architectural paint films-A review. Int. Biodeterior. Biodegrad. 2011, 65, 1189-1198. [CrossRef]

20. Grüll, G.; Truskaller, M.; Podgorski, L.; Bollmus, S.; Tscherne, F. Maintenance procedures and definition of limit states for exterior wood coatings. Eur. J. Wood Wood Prod. 2011, 69, 443-450. [CrossRef]

21. Dawson, B.S.; Singh, A.P.; Kroese, H.W.; Schwitzer, M.A.; Gallagher, S.; Riddiough, S.J.; Wu, S. Enhancing exterior performance of clear coatings through photostabilization of wood. Part 2: Coating and weathering performance. J. Coat. Technol. Res. 2008, 5, 207-219. [CrossRef]

22. Van den Bulcke, J.; De Windt, I.; Defoirdt, N.; De Smet, J.; Van Acker, J. Moisture dynamics and fungal susceptibility of plywood. Int. Biodeterior. Biodegrad. 2011, 65, 708-716. [CrossRef]

23. Grüll, G.; Tscherne, F.; Spitaler, I.; Forsthuber, B. Comparison of wood coating durability in natural weathering and artificial weathering using fluorescent UV-lamps and water. Eur. J. Wood Wood Prod. 2014, 72, 367-376. [CrossRef]

24. Žlahtič, M.; Humar, M. Influence of artificial and natural weathering on the hydrophobicity and surface properties of wood. BioResources 2016, 11, 4964-4989. [CrossRef]

25. Miklečić, J.; Turkulin, H.; Jirouš-Rajković, V. Weathering performance of surface of thermally modified wood finished with nanoparticles-modified waterborne polyacrylate coatings. Appl. Surf. Sci. 2017, 408, 103-109. [CrossRef]

26. EN 927-3. Paints and Varnishes. Coating Materials and Coating System for Exterior Wood, Part 3: Natural Weathering Test; European Committee for Standardization: Brussels, Belgium, 2006.

27. EN 927-6. Paints and Varnishes. Coating Materials and Coating Systems for Exterior Wood, Part 6: Exposure of Wood Coatings to Artificial Weathering Using Fluorescent UV Lamps and Water; European Committee for Standardization: Brussels, Belgium, 2006.

28. Reinprecht, L.; Pánek, M. Effects of wood roughness, light pigments, and water repellent on the color stability of painted spruce subjected to natural and accelerated weathering. BioResources 2015, 10, 7203-7219. [CrossRef]

29. Deflorian, F.; Rossi, S.; Fedrizzi, L.; Zanella, C. Comparison of organic coating accelerated tests and natural weathering considering meteorological data. Prog. Org. Coat. 2007, 59, 244-250. [CrossRef] 
30. Moya, R.; Rodríguez-Zúñiga, A.; Vega-Baudrit, J.; Puente-Urbina, A. Effects of adding $\mathrm{TiO}_{2}$ nanoparticles to a water-based varnish for wood applied to nine tropical woods of Costa Rica exposed to natural and accelerated weathering. J. Coat. Technol. Res. 2017, 14, 141-152. [CrossRef]

31. Oberhofnerová, E.; Pánek, M.; Böhm, M. Effect of surface pretreatment with natural essential oils on the weathering performance of spruce wood. BioResources 2018, 13, 7053-7070. [CrossRef]

32. Valverde, J.C.; Moya, R. Correlation and modeling between color variation and quality of the surface between accelerated and natural tropical weathering in Acacia mangium, Cedrela odorata and Tectona grandis wood with two coating. Color Res. Appl. 2014, 39, 519-529. [CrossRef]

33. Jirous-Rajkovic, V.; Bogner, A.; Radovan, D. The efficiency of various treatments in protecting wood surfaces against weathering. Surf. Coat. Int. B Coat. Trans. 2004, 87, 15-19. [CrossRef]

34. Merlatti, C.; Perrin, F.X.; Aragon, E.; Margaillan, A. Natural and artificial weathering characteristics of stabilized acrylic-urethane paints. Polym. Degrad. Stab. 2008, 93, 896-903. [CrossRef]

35. Oltean, L.; Teischinger, A.; Hansmann, C. Wood surface discolouration due to simulated indoor sunlight exposure. Holz Roh-und Werkst. 2008, 66, 51. [CrossRef]

36. Creemers, J.; De Meijer, M.; Zimmermann, T.; Sell, J. Influence of climatic factors on the weathering of coated wood. Eur. J. Wood Wood Prod. 2002, 60, 411-420. [CrossRef]

37. ČSN 49 0108. Drevo. Zist'ovanie Hustoty [Wood. Determination of the Density]; Český Normalizační Institut: Prague, Czech Republic, 1993.

38. Meteostation of the Faculty of Agronomy-Department of Agroecology and Biometeorology, Prague, Czech Republic. 2019. Available online: http://meteostanice.agrobiologie.cz (accessed on 27 November 2019).

39. Pánek, M.; Oberhofnerová, E.; Zeidler, A.; Šedivka, P. Efficacy of hydrophobic coatings in protecting oak wood surfaces during accelerated weathering. Coatings 2017, 7, 172. [CrossRef]

40. Commission Internationale de l'Eclairage (CIE). Colorimetry, 2nd ed.; (CIE Pub. No. 15.2); Commission Internationale de l'Eclairage: Vienna, Austria, 1986.

41. EN ISO 2813. Paints and Varnishes-Determination of Gloss Value at 20 Degrees, 60 Degrees and 85 Degrees; European Committee for Standardization: Brussels, Belgium, 2014.

42. Bastani, A.; Adamopoulos, S.; Militz, H. Water uptake and wetting behaviour of furfurylated, N-methylol melamine modified and heat-treated wood. Eur. J. Wood Wood Prod. 2015, 73, 627-634. [CrossRef]

43. Ozgenc, O.; Hiziroglu, S.; Yildiz, U.C. Weathering properties of wood species treated with different coating applications. BioResources 2012, 7, 4875-4888. [CrossRef]

44. Turkoglu, T.; Baysal, E.; Toker, H. The effects of natural weathering on color stability of impregnated and varnished wood materials. Adv. Mater. Sci. Eng. 2015. [CrossRef]

45. Sehlstedt-Persson, M. Color responses to heat-treatment of extractives and sap from pine and spruce. In Proceedings of the 8th IUFRO International Wood Drying Conference: Improvement and Innovation in Wood Drying: A Major Issue for a Renewable Material, Brasov, Romania, 24-29 August 2003; Faculty of Wood Industry, Transilvania University of Brasov: Brasov, Romania, 2003; pp. 459-464.

46. Ghosh, M.; Gupta, S.; Kumar, V.S. Studies on the loss of gloss of shellac and polyurethane finishes exposed to UV. Maderas Ciencia y Tecnología 2015, 17, 39-44. [CrossRef]

47. Kubovský, I.; Oberhofnerová, E.; Kačík, F.; Pánek, M. Surface changes of selected hardwoods due to weather conditions. Forests 2018, 9, 557. [CrossRef]

48. Sivrikaya, H.; Hafizoglu, H.; Yasav, A.; Aydemir, D. Natural weathering of oak (Quercus petrae) and chestnut (Castanea sativa) coated with various finishes. Color Res. Appl. 2011, 36, 72-78. [CrossRef]

49. Temiz, A.; Terziev, N.; Eikenes, M.; Hafren, J. Effect of accelerated weathering on surface chemistry of modified wood. Appl. Surf. Sci. 2007, 253, 5355-5362. [CrossRef]

50. Singh, T.; Singh, A.P. A review on natural products as wood protectant. Wood Sci. Technol. 2012, 46, 851-870. [CrossRef]

51. Pánek, M.; Reinprecht, L. Colour stability and surface defects of naturally aged wood treated with transparent paints for exterior constructions. Wood Res. 2014, 59, 421-430.

52. Pánek, M.; Reinprecht, L. Critical view on the possibility of color changes prediction in the surfaces of painted wood exposed outdoors using accelerated weathering in Xenotest. J. Coat. Technol. Res. 2019, 16, 339-352. [CrossRef] 
53. Q-LAB. Correlation of Laboratory to Natural Weathering. Technical Bulletin LU-0824. 1977. Available online: www.q-lab.com/resources/technical-articles.aspx (accessed on 16 December 2019).

54. Mattos, B.D.; De Cademartori, P.H.G.; Lourençon, T.V.; Gatto, D.A. Colour changes of Brazilian eucalypts wood by natural weathering. Int. Wood Prod. J. 2014, 5, 33-38. [CrossRef]

(C) 2019 by the authors. Licensee MDPI, Basel, Switzerland. This article is an open access article distributed under the terms and conditions of the Creative Commons Attribution (CC BY) license (http://creativecommons.org/licenses/by/4.0/). 